\title{
学術・技術論文
}

\section{最適力配分を考慮した計算トルク法に基づく 節体幹型移動ロボットの姿勢制御の提案}

\author{
福 島 E. 文 彦* 広 瀬 茂 男* \\ A Computed Torque Method Based Attitude Control with \\ Optimal Force Distribution for Articulated Body Mobile Robots
}

Edwardo F. Fukushima* and Shigeo Hirose*

\begin{abstract}
This paper introduces an attitude control scheme based in optimal force distribution using quadratic programming which minimizes joint energy consumption. This method shares similarities with force distribution for multifingered hands, multiple coordinated manipulators and legged walking robots. In particular, an attitude control scheme was introduced inside the force distribution problem, and successfully implemented for control of the articulated body mobile robot KR-II. This is an actual mobile robot composed of cylindrical segments linked in series by prismatic joints and has a long snake-like appearance. These prismatic joints are force controlled so that each segment's vertical motion can automatically follow the terrain irregularities. An attitude control is necessary because this system acts like a system of wheeled inverted pendulum carts connected in series, being unstable by nature. The validity and effectiveness of the proposed method is verified by computer simulation and experiments with the real robot KR-II.
\end{abstract}

Key Words: Attitude Control, Force Distribution, Computed Torque Method, Quadratic Programming, Articulated Body Mobile Robot

1.は じめに

我々は節体幹型移動ロボット「蛟龍」を開発している。これ は, 災害現場での偵察, 原子炉内での巡回検査や補修, そして 森林作業のように危険を伴う作業などを人間に代わって行うた めの移動能力や積載能力を有する. 例えば, 複数節を同時に持 ち上げて溝やパイプなどの無接触乗り越え, ヘビのように狭险 な通路を移動したり，屋内や屋外環境を自由に移動ができる。 節体幹型移動ロボット「蛟龍」に類似した形態のロボットにつ いての研究としては超多自由度システム $[4] \sim[7]$ や, 車輪型移 動ロボットの運動解析法 [8]〜 [10] などがあるが, 実際の機械モ デルを構築し実験的立場で行った研究は少ない.しかし, 最近 では [11]〜 [13]のように蛇型移動ロボットの研究に積極的な取 り組みも見受けられ, 近い将来には何種類かの蛇型ロボットが 完成され上述の環境などで活躍するものと期待できる.

筆者らはFig 1 に示す 7 節から構成された「蛟龍」第 2 号機 モデル KR-II を試作した [2]. KR-II は，Fig 2 (a) (b) に示す ようにi）節前部 $\mathrm{FP}$, ii) 節後部 $\mathrm{RP}$, iii）ステアリング・プ レート SP, iv) 中間連結プレート IP, v) 車輪部 Wh, そして vi）節前部連結面 Pfからなる共通の「ユニット節」を複数直列 連結して構成される。ただし, 各ユニット節の車輪は左右交互

原稿受付 1999 年 4 月 8 日

*東京工業大学

${ }^{*}$ Tokyo Institute of Technology
に片輪構成で配置され, また先頭節にはマニピュレータが装備 されている．各ユニット節は節前部 FPに対する節前部連結面 $\operatorname{Pf} の$ 上下並進自由度 ( $\mathrm{z}$ 軸), 節中心軸回りの節前部 FP と節 後部 RP の相対旋回自由度 $(\theta$ 軸), そして各節の能動車輪に よる推進自由度 ( $\mathrm{s}$ 軸) の三つの能動自由度を備えている. 第 $n$ 節の節前部連結面 Pf は隣前の第 $(n-1)$ 節の節後部 RP に 連結固定されるためすべての節の $\mathrm{z}$ 軸は同方向を向く．そのた め, 任意の節の姿勢を測定することで全体の姿勢は推定できる. $\mathrm{KR}-\mathrm{II}$ では第 3 節の前部に胴体固定の座標系 $\Sigma_{B}$ を設定し, 重 力加速度方向と直交する水平面に対する $\Sigma_{B}$ の $X_{B}$ と $Y_{B}$ 軸

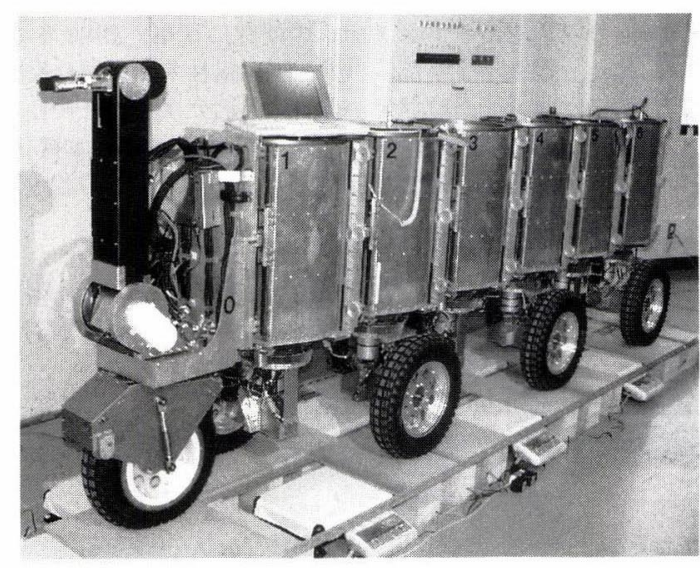

Fig. 1 Articulated body mobile robot KR-II 

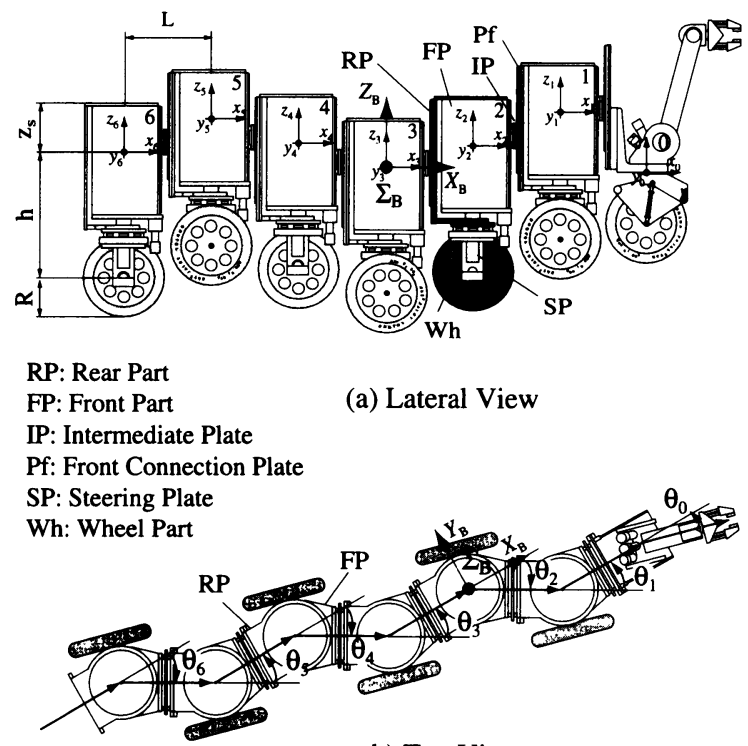

(b) Top View

Fig. 2 KR-II's mechanism and motion variables

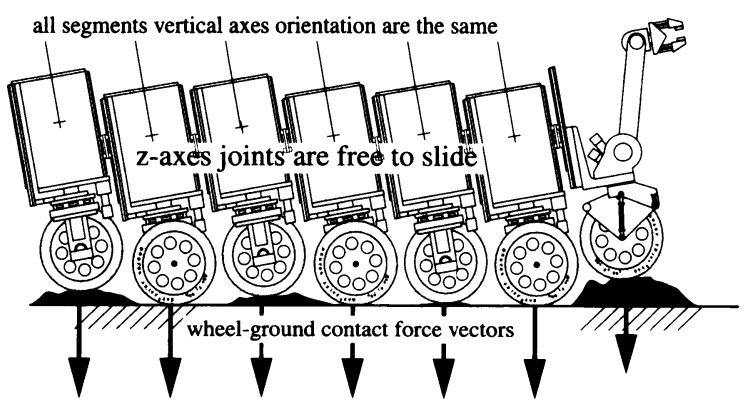

Fig. 3 Posture change under simple $z$-axes force control

回りの角度 $\phi_{X}, \phi_{Y}$ を $\mathrm{KR}$ の姿勢として定義する。これらの 傾き角度を調整するのが「姿勢制御」の目的である。このよう な $\mathrm{KR}$ が高度な対地適応性を発揮するには， $\mathrm{z}$ 軸の力制御が不 可欠である. $\mathrm{z}$ 軸を力制御し, 車輪と路面間の接地力の変化に 応じて各節を能動的に上下させれば，各車輪は路面の凹凸に自 動的に追従できる.ところが, すべての $\mathrm{z}$ 軸力目標值をゼロと する最も基本的な制御法のみでは KR-II の隣接する節同士が 自由に滑り, Fig 3 に示すように複数の倒立振子を直列連結し たような系と同等に振る舞い，最期には全体が転倒する。その ため, $\mathrm{z}$ 軸力制御は姿勢制御と組み合わせて実施しなければな らない。

蛟龍の姿勢制御問題は研究の初期から検討され，まずはじ めに第 1 次機械モデル KR-I を対象に逆運動学的手法に基づ いた姿勢制御法 [1] が考案された。具体的にはi）蛟龍の隣接 する節の中心を結ぶ節ベクトル $\boldsymbol{L}_{i} \in \boldsymbol{R}^{3}$ を設定し, ii）垂直 状態から傾いた姿勢での節べクトルを $\boldsymbol{L}_{i}^{\prime}=\boldsymbol{E}^{j \phi_{p}} \boldsymbol{E}^{i \phi_{r}} \boldsymbol{L}_{i}$ と 求め, iii）姿勢制御に必要な各関節の制御量 $\delta \mathrm{z}, \delta \theta$ と $\delta \mathrm{s}$ を $d \boldsymbol{L}_{i}=\boldsymbol{L}_{i}^{\prime}-\boldsymbol{L}_{i}$ の関係式から求めるという制御法であった。 た だし， $\boldsymbol{E}^{j \phi_{p}}$ と $\boldsymbol{E}^{i \phi_{r}}$ はそれぞれ $\mathrm{y}$ 軸と $\mathrm{x}$ 軸回りの座標回転行 列, $\phi_{r}$ はロール角, $\phi_{p}$ はピッチ角である [14]. 本制御法で求 められた $\mathrm{z}$ 軸の位置変位量 $\delta \mathrm{z}$ は $\mathrm{z}$ 軸の力と変位を考慮したイン
ピーダンス関係を用いて力目標値に変換し用いていた $[1]$. 同様 な姿勢制御法は KR-IIにも適用した。ところが，運動学手法に 基づいた本姿勢制御は, 蛟龍のすべての車輪が路面と接地して いる場合には有効であったが, 溝の乗り越えやパイプの跨ぎ越 えのように節支持力の著しい変化が発生する運動では十分な姿 勢安定性は得られていなかった。 そのため, 全体の力・モーメ ントの釣合い式を考慮した最適化問題を定式化し, 力のフィー ドフォワード補償 [19] を上記運動学手法と組み合わせた姿勢制 御法を導入しこの問題の解決を試みた。 また, バランス式に復 帰モーメントを発生する姿勢フィードバック項も導入し, バラ ンス式のみに基づいた姿勢制御の提案も行った [20]. 本論文で は, [19] [20] で筆者らが行ってきた「蛟龍」の姿勢制御問題を再 度概観し, これとロボット工学においてこれまで研究されてき ている多指ハンドの最適把持力, 複数マニピュレータによる対 象物の操りや脚型ロボットの力配分問題との共通点を指摘し, より望ましい制御側を求めることにする.

本論文では，まず第 2 章で多指ハンドなどの最適力配分問題 の研究背景について論議し, 一般のマルティボディシステムと の定式化の共通性を示す. 第 3 章では関節力の最小化を目的関 数とした一般的な最適化問題の定式化と解法を説明する. 次い で, 第 4 章では KR-II に対する最適力配分問題の定式化と, 姿 勢フィードバック項の導入方法を示す. 第 5 章では障害物の跨 ぎ越え動作のシミュレーション結果を示し, 第 6 章ではその実 験結果を示して本論文で提案する制御法の妥当性を検証する.

\section{2. 最適力配分問題の研究背景}

路面と複数点で接触して閉ループ連鎖を構成する移動ロボッ ト（特に脚型や節体幹型）では力の不静定問題が生じる。つま り, バランス式の数よりも外部環境との接触力未知数の方が多 いため, バランス式を満たす力配分の組み合わせは無数解存在 し，一意には定まらない。これは節体幹型移動ロボット特有の 問題ではなく, 多指ハンド, 複数マニピュレータによるあやつ り制御や脚型ロボットの力配分問題として従来から研究されて きた [15]〜 [26]. 以下にそれらの基本概念を示す.

\section{1 対象物のバランス式}

多指ハンド・複数マニピュレータの把持や協調あやつりの対 象になる物体や脚型ロボットの胴体部分は Fig 4 (a) に示すよ うに単体の「対象物 (reference member)」としてモデル化で き,その運動は指, マニピュレータや脚を構成するリンク系と 独立に扱うことができる，いま，外部と $k$ 個の接触点を有す る Fig 4 (a)の対象物に対して, 質量 $m_{0}$, 対象物重心の加速度 と角加速度 $\boldsymbol{\alpha}_{0}, \boldsymbol{\omega}_{0} \in \boldsymbol{R}^{3}$, 重心座標系に対する慣性テンソル $\boldsymbol{H}_{0} \in \boldsymbol{R}^{3 \times 3}$, 第 $i$ 番目の接触点に加わる力 $\boldsymbol{F}_{i} \in \boldsymbol{R}^{3}$ とモー メント $\boldsymbol{M}_{i} \in \boldsymbol{R}^{3}$, 対象物の重心座標系からみた接触点の位置 $\boldsymbol{p}_{i}=\left[\begin{array}{lll}p_{i 1} & p_{i 2} & p_{i 3}\end{array}\right]^{T} \in \boldsymbol{R}^{3}$ を定義する. 外力によって物体 に加わる合力と合モーメントは $\boldsymbol{F}_{0}=\sum_{i=1}^{k} \boldsymbol{F}_{i} \in \boldsymbol{R}^{3}$, そして $\boldsymbol{M}_{0}=\sum_{i=1}^{k}\left(\boldsymbol{M}_{i}+\boldsymbol{p}_{i} \times \boldsymbol{F}_{i}\right) \in \boldsymbol{R}^{3}$ として表され, 対象物の 運動は

$$
\begin{aligned}
m_{0}\left(\boldsymbol{\alpha}_{0}-\boldsymbol{g}\right) & =\boldsymbol{F}_{0} \\
\boldsymbol{H}_{0} \dot{\boldsymbol{\omega}}_{0}+\boldsymbol{\omega}_{0} \times\left(\boldsymbol{H}_{0} \boldsymbol{\omega}_{0}\right) & =\boldsymbol{M}_{0}
\end{aligned}
$$




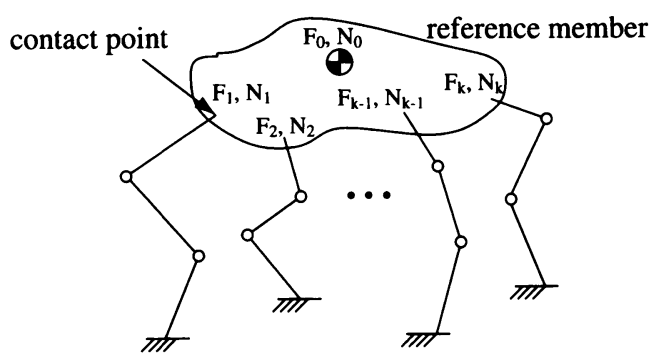

(a) Multifingered hands, multiple coordinated manipulators and legged walking robots

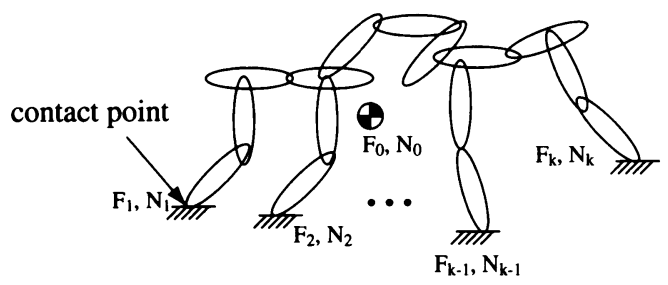

(b) A general multibody system (KR included)

Fig. 4 Comparison of single and multi-body systems

として表される．ただし，本来なら外力として扱うべき重力加 速度 $\boldsymbol{g}$ の項は表記の便宜上式（1）に加えた。慣性力による式 （1）（2）の各項を $\boldsymbol{Q} \in \boldsymbol{R}^{6}$ としてまとめ，外力による項を行 列 $\boldsymbol{P}$ と接触力ベクトル $\boldsymbol{N}$ を

$$
\begin{aligned}
& \boldsymbol{P}=\left[\begin{array}{ccccccc}
\boldsymbol{I}_{3} & 0 & \boldsymbol{I}_{3} & 0 & \cdots & \boldsymbol{I}_{3} & 0 \\
\tilde{\boldsymbol{p}}_{1} & \boldsymbol{I}_{3} & \tilde{\boldsymbol{p}}_{2} & \boldsymbol{I}_{3} & \cdots & \tilde{\boldsymbol{p}}_{k} & \boldsymbol{I}_{3}
\end{array}\right] \in \boldsymbol{R}^{6 \times 6 k} \\
& \tilde{\boldsymbol{p}}_{i}=\left[\begin{array}{ccc}
0 & -p_{i 3} & p_{i 2} \\
p_{i 3} & 0 & -p_{i 1} \\
-p_{i 2} & p_{i 1} & 0
\end{array}\right] \in \boldsymbol{R}^{3 \times 3} \\
& \boldsymbol{I}_{3} \in \boldsymbol{R}^{3 \times 3} \text { : Identity Matrix } \\
& \boldsymbol{N}=\left[\begin{array}{lllll}
\boldsymbol{F}_{1}^{T} & \boldsymbol{M}_{1}^{T} & \cdots & \boldsymbol{F}_{k}^{T} & \boldsymbol{M}_{k}^{T}
\end{array}\right]^{T} \in \boldsymbol{R}^{6 k}
\end{aligned}
$$

としてまとめるとバランス式は以下の線形方程式で記述できる.

$$
\boldsymbol{Q}=\boldsymbol{P} \boldsymbol{N}
$$

\section{1 .1 一般的な解法}

式（5）で表されるバランス式に対する接触力 $N$ の一般解は

$$
\boldsymbol{N}=\boldsymbol{P}^{+} \boldsymbol{Q}+\left(\boldsymbol{I}-\boldsymbol{P}^{+} \boldsymbol{P}\right) \boldsymbol{\lambda}
$$

となる [16] [17]. ただし， $\boldsymbol{P}^{+}$は一般化疑似逆行列である.

上記の一般解に対して, 内力と力配分問題の基礎を示した具 体的な最適問題の定式化は Kerr, Roth [15]らによって行われ た. 基本的な概念としては，i）一般解は $N=N_{e}+N_{i}$ のよ うに二つの直交するべクトルで与えられ，ii）部分問題 $N_{e}$ は $\boldsymbol{N}_{e}=\boldsymbol{P}^{+} \boldsymbol{Q}$ のように疑似逆行列を用いて求まる. そして, iii) 部分解 $\boldsymbol{N}_{i}$ は $\boldsymbol{P}$ の零空間に位置するべクトルであるので内力 に相当する. iv) $\left(\boldsymbol{I}-\boldsymbol{P}^{+} \boldsymbol{P}\right)$ に対応する行列は $\boldsymbol{P}$ の零空間の 正規直交基底ベクトルで構成された行列であり，入は内力の大 きさを示すべクトルとなる。これらの概念を利用し, 彼らは指
先接触点での摩擦力や関節駆動力を考慮した線形計画法に基づ いた定式化を行い，入の最適解を求めている.

実際, 文献 [23]にも詳しく説明されている通り,グリッパや ハンドの最適力配分問題は内力 $\boldsymbol{\lambda}$ の解を求める問題に帰着し ている。これまで, 最適化対象の目的関数や制約条件などに よって色々な解法が提案されてきたが，それらは線形計画法と 2 次計画問題の二つに分類できる。そその中で, 中村 [16] [18] ら の接触力ノルム $\|\boldsymbol{N}\|$ 最小化問題は初めて非線形問題を扱った 論文である。彼らはラグランジュ未定係数法に基づいた独自の 非線形計画法の解法アルゴリズムを提案している。非線形計画 法の実時間制御性や解の不連続性などを指摘し, 線形計画法の 効率化を目的とした幾つかの研究 [21] [24]もその後発表された. Nahon と Angeles [22]は関節力や内力ノルムの最小化問題は 2 次計画問題として統一的に定式化できることを指摘した。そ してこの問題は Goldfarb と Idnami [27] が提案した効率的な 方法で実時間に解くことが可能であることが示された．現在で は本研究の基本概念を発展させた 2 次計画問題に基づいた研究 が盛んである [25] [26]. ただし, Nahon と Angelesの定式化は 概念的には中村らの定式化と同じである。

\section{2 マルティボディシステムとの共通性}

複雑なリンク系から構成される Fig 4 (b) のようなマルティボ デイシステムでは，一般的には対象物となり得る共通の部分が 存在しない。また，物理的な観点からはFig 4(a) (b)のシステ ムでは接触点での力やモーメント $\boldsymbol{F}_{i}, \boldsymbol{M}_{i}$ の発生メカニズムが 異なる。つまり，(a)では指，マニピュレータや脚の運動によっ て外部から対象物に力が加わる。 それに対して, 外部環境との 間に接触点を有する $(\mathrm{b})$ では，一般的には路面などの外部環境 からは力は作用されず，重力加速度と内部運動によって接触点 での力を発生している，ところが，これらのシステムの数学的 モデルは以下のように共通している。

\section{2 .1 バランス式}

Fig 4 (b) のマルティボディシステムにおいて $k, \boldsymbol{F}_{i}, \boldsymbol{M}_{i}, \boldsymbol{p}_{i}$ をFig 4 (a) と同様に定義し, 系全体の重心に発生する外力に よる合力と合モーメントを求めると単体の物体に対する式 (3) （4）と同じょうにまとめられる。一方，慣性力による項はもち ろん式（1）（2）と一致しない.しかし， $\boldsymbol{q}$ を一般化座標系とし， マルティボディシステムを構成する各質点系に生じる慣性力を 考慮すれば系全体の重心に発生する力は一般的に $\boldsymbol{Q}(\boldsymbol{q}, \dot{\boldsymbol{q}}, \ddot{\boldsymbol{q}})$ の ように $\boldsymbol{q}, \dot{\boldsymbol{q}}, \ddot{\boldsymbol{q}}$ の関数として求めることが可能であるので, バ ランス式は一般的に

$$
\boldsymbol{Q}(\boldsymbol{q}, \dot{\boldsymbol{q}}, \ddot{\boldsymbol{q}})=\boldsymbol{P} \boldsymbol{N}
$$

のような線形方程式で記述できる. 式 (7) と式 (5) は数式的 に同じであるため, 2.1 .1 節で説明した単体の物体に対する従 来からの議論はマルティボディシステムにも適用できる.

\subsection{2 運動方程式}

Fig 4(a)のシステムでは接触力ベクトル $\boldsymbol{N}$ と各リンク系で 発生すべき関節力 $\boldsymbol{\tau}$ を求める問題はそれぞれ独立に定式化で き, $k$ 個のリンク系に対する演算は独立で並列に実施できる利 点を有する.しかし，多くの場合には全体の関節力 $\boldsymbol{\tau}$ を最適化 
するのが望ましく，その目的のためには全体の運動方程式を以 下のように整理できる [17].

$$
\boldsymbol{\tau}=\boldsymbol{H} \ddot{\boldsymbol{q}}+\boldsymbol{C}+\boldsymbol{G}_{g}+\boldsymbol{J}^{T} \boldsymbol{N}
$$

ただし， $\boldsymbol{H}$ は慣性項， $\boldsymbol{C}$ は遠心力とコリオリカによる項， $\boldsymbol{G}_{g}$ は重力項, $\boldsymbol{J}$ はヤコビ行列である. 周知の通り, ロボットマニ ピュレータやマルティボディシステムに対する運動方程式も一 般的に式（8）のように記述できる. 結局, 運動方程式に関して も Fig 4 (a) と (b) のシステムは数式的に同じであり, マルティ ボディシステムと多指ハンドなどの研究は統一的に議論できる ことがわかる.

\section{3. 関節力最小化問題の定式化}

\section{1 目的関数}

ロボットが低速で高出力運動を行う場合, サーボモータの電 機子抵抗での消費パワーから消費エネルギを見積ることが可能 である．そのため, 本論文では関節力变数 $\boldsymbol{\tau}$ の 2 乗和

$$
S(\boldsymbol{\tau})=\boldsymbol{\tau}^{T} \boldsymbol{W} \boldsymbol{\tau}
$$

を評価関数としてエネルギ最小化問題を考える。ただし，W は対称正定な重み行列である. いま, $\boldsymbol{H}_{q}=\boldsymbol{H} \ddot{\boldsymbol{q}}+\boldsymbol{C}+\boldsymbol{G}_{g}$, $\boldsymbol{G}=2 \boldsymbol{J} \boldsymbol{W} \boldsymbol{J}^{T}$, そして $\boldsymbol{d}=2 \boldsymbol{J} \boldsymbol{W} \boldsymbol{H}_{q}$ のような補助項を定義 して式（8）を式（9）に代入すると, 評価関数は以下のように 与えられる。

$$
S(\boldsymbol{\tau})=\boldsymbol{H}_{q}^{T} \boldsymbol{W} \boldsymbol{H}_{q}+\boldsymbol{d}^{T} \boldsymbol{N}+\frac{1}{2} \boldsymbol{N}^{T} \boldsymbol{G} \boldsymbol{N}
$$

\subsection{2 次計画問題の定式化}

接触力 $\boldsymbol{N}$ に依存しない右辺第 1 項を目的関数から排除すれ ば, 式（10）は $\boldsymbol{N}$ を変数とした式（11）で示される。また, 接触力 $\boldsymbol{N}$ についての線形制約条件を式（12）のように定義す れば，関節力のノルム最小化問題は式（11）(12）で与えられ る一般的な 2 次計画問題に帰着する。

$$
\begin{aligned}
& \underset{\boldsymbol{N}}{\min .:} \quad S(\boldsymbol{N})=\boldsymbol{d}^{T} \boldsymbol{N}+\frac{1}{2} \boldsymbol{N}^{T} \boldsymbol{G} \boldsymbol{N} \\
& \text { subject to: }\left\{\begin{array}{l}
\boldsymbol{P}_{e} \boldsymbol{N}=\boldsymbol{Q}_{e} \\
\boldsymbol{P}_{i} \boldsymbol{N} \geq \boldsymbol{Q}_{i}
\end{array}\right.
\end{aligned}
$$

式（12）の等式制約条件は一般には式（5）や（7）で与えら れ, 不等式制約条件は摩擦力, 接触力や関節力などの最大・最 小值条件から得られる。ここで, 重み行列 $\boldsymbol{W}$ は正定值であ ることから問題は凸計画問題となる。このような, 等式制約条 件と不等式制約条件での効率的な解法はすでに検討されている $[27] \sim[29]$.

\section{3 等式制約条件のみを考慮した一般解}

上記問題に対して等式制約条件のみを考慮した部分最適解は 一般疑似逆行列 $\boldsymbol{P}_{e}^{+}$を

$$
\boldsymbol{P}_{e}^{+}=\boldsymbol{G}^{-1} \boldsymbol{P}_{e}^{T}\left(\boldsymbol{P}_{e} \boldsymbol{G}^{-1} \boldsymbol{P}_{e}^{T}\right)^{-1}
$$

とし, 補助行列 $\boldsymbol{H}_{e}$ を

$$
\boldsymbol{H}_{e}=\left(\boldsymbol{I}-\boldsymbol{P}_{e}^{+} \boldsymbol{P}_{e}\right) \boldsymbol{G}^{-1}
$$

と定義すれば

$$
\boldsymbol{N}_{e}=\boldsymbol{P}_{e}^{+} \boldsymbol{Q}_{e}-\boldsymbol{H}_{e} \boldsymbol{d}
$$

のように求まる.

ここで, 式 (15) の右辺第 1 項は接触力 $\boldsymbol{N}$ のノルム, つま り目的関数 $\boldsymbol{N}^{T} \boldsymbol{G N}$ を最小にする特殊解に相当する。このこ とに注目すれば，右辺第 2 項は関節力 $\boldsymbol{\tau}$ のノルム最小化を目 的関数に含めた分の特殊解であると解釈できる.この解は $\boldsymbol{P}_{e}$ の零空間内に存在するが, 解析的な数式解として求まることが 特徵的である。

\section{4 不等式制約条件付問題の解法}

不等式制約条件を考慮した問題の場合には一般的には解析解 は存在せず, 解法は収束条件を評価しながら探索的に求められ る.この探索の出発点としては式 (15) のような等式制約条件 部分問題の解を用いることが有効である. 完全な解法について は例えば文献 [16] [22] [27]〜 [29] などで論じられている.

本論文では，筆者らが従来から提案してきた実時間制御に 適した効率的な解法アルゴリズムを使用することにする $[20]$. これは，指，ハンド，脚や車輪などは構造的に対象物を押すこ とはできるが, 引くことはできないことに着目し, 負の接触 力の発生を制限する不等式制約条件のみを考慮したものであ る. 具体的には, 式 (12) の等式制約条件項に対してバラン ス式の項 $\boldsymbol{P} \boldsymbol{N}=\boldsymbol{Q}$ 以外に目標接触力を直接指示するための $\boldsymbol{P}_{d} \boldsymbol{N}=\boldsymbol{Q}_{d} \in \boldsymbol{R}^{d}$ 項を新たに導入し,

$$
\begin{aligned}
& \boldsymbol{P}_{e}=\left[\begin{array}{ll}
\boldsymbol{P}^{T} & \boldsymbol{P}_{d}^{T}
\end{array}\right]^{T} \\
& \boldsymbol{Q}_{e}=\left[\begin{array}{ll}
\boldsymbol{Q}^{T} & \boldsymbol{Q}_{d}^{T}
\end{array}\right]^{T}
\end{aligned}
$$

として, 負の接触力が生成された点の接触力を強制的にゼロに なるように設定して解くものでる。ただし，dは目標値を強制 的に設定する接触力の数を表す变数である. 以下に具体的なア ルゴリズムを示す.

Step 0. 初期化： $d_{0}$ 個の目標接触力が $\boldsymbol{P}_{d} \boldsymbol{N}=\boldsymbol{Q}_{d} \in \boldsymbol{R}^{d_{0}}$ で 与えられた場合には式（16）（17）に考慮し， $d=d_{0}$ と する. $d_{0}=0$ の場合には $d=0, \boldsymbol{P}_{e}=\boldsymbol{P}, \boldsymbol{Q}_{e}=\boldsymbol{Q}$ と初期化する.

Step 1. 等式制約条件のみを考慮した部分最適化問題の解 $\boldsymbol{N}_{e}$ を式 (15) から求める.

Step 2. $\boldsymbol{N}_{e}$ に負の接触力が生成されたならば，その数を $d_{n}$ とし, 次に進む. 生成されなければ式 (18) から関節力 を求め終了する.

$$
\boldsymbol{\tau}_{e}=\boldsymbol{H}_{q}+\boldsymbol{J}^{T} \boldsymbol{N}_{\boldsymbol{e}}
$$

Step 3. $d=d+d_{n}$ と更新し, $d \leq$ (自由変数の数 - バラン ス式の数) であれば次に進む。そうでなければ終了する (問題は解けない).

Step 4. 負の接触力が生成された接触点に対して目標接触力を ゼロに設定して等式制的条件 $\boldsymbol{P}_{d} \boldsymbol{N}=\boldsymbol{Q}_{d}$ に加え, Step 1.に戻る。

本アルゴリズムは実時間制御に適している反面, 完全な解法 ではないので必ずしも解が得られることは保証されない.それ 
は, 本アルゴリズムではすべての接触力の組み合わせを探索し ないため，実際には解が存在するにもかかわらず Step 3. で終 了する場合も存在し得ることを意味する。しかし，全体のバラ ンスがとれない場合には確実にStep 3. で問題は終了すること は保証され, 本アルゴリズムは安全方向に働く.

実際，KR-II では先頭の三節を同時に持ち上げるような明ら かにバランスが保てない動作では問題は有限回の反復計算の後, Step 3. で終了する.しかし, KR-II の操舵運動, 溝の乗り越 えやパイプの跨ぎ越え, そして姿勢制御の通常の運動計画では, 必ず有限回の反復によって実現可能な解が得られる。 その様子 を第 5 章のパイプ跨ぎ越え動作のシミュレーションで示す.

\section{KR-II の姿勢制御の定式化}

\section{1 全体のモデル化}

マニピュレータ部を除いた KR-II 全体の一般化座標系 $\boldsymbol{q}$ は $\mathrm{z}$ 軸の並進量 $\boldsymbol{z}=\left[\begin{array}{llll}z_{1} & z_{2} & \cdots & z_{6}\end{array}\right]^{T} \in \boldsymbol{R}^{6}, \theta$ 軸の旋回角度 $\boldsymbol{\theta}=$ $\left[\theta_{0} \theta_{1} \cdots \theta_{6}\right]^{T} \in \boldsymbol{R}^{7}$, 車輪の回転量 $\boldsymbol{s}=\left[\begin{array}{ll}s_{0} & s_{1} \cdots s_{6}\end{array}\right]^{T} \in \boldsymbol{R}^{7}$, そして慣性座標系に対する胴体座標系の位置 $\boldsymbol{c}_{0}=\left[\begin{array}{lll}x_{0} & y_{0} & z_{0}\end{array}\right]^{T}$ と姿勢角度 $\phi=\left[\begin{array}{lll}\phi_{X} & \phi_{Y} & \phi_{Z}\end{array}\right]^{T}$ の計 26 自由度で記述できる. また, 実機に対する各部の質量, 慣性モーメントと質量中心は Table 1 に示す通りである．ただし，第 $n$ 節の節前部連結面 Pf は隣前の第 $(n-1)$ 節の節後部 RP に連結固定されているた め RP の特性に加えた。 また各節別に増設された装置類（Extra loads）はそれぞれの節前部 FP の慣性情報に加えて考慮した。

このような KR-II に対して式（7）（8）で与えられるバラン ス式と運動方程式の各項はニュートン・オイラー法, ラグラン ジュ法，または仮想パワーに基づいた方法 [10] などによって求 められる. 本研究では以下に示す車輪部のモデル化と諸簡略化 条件の下で全体の解析解をニュートン・オイラー法によって求

Table 1 KR-II's inertial parameters

\begin{tabular}{|c|l|r|c|c|c||r|r|r|}
\hline \multirow{2}{*}{ Seg } & \multirow{2}{*}{ Part } & mass & \multicolumn{3}{|c||}{ Inertia[kg m $\left.{ }^{2}\right]$} & \multicolumn{4}{|c|}{ mass center $[\mathrm{mm}]$} \\
\cline { 4 - 9 } & & {$[\mathrm{kg}]$} & $I_{x}$ & $I_{y}$ & $I_{z}$ & $p_{x}$ & $p_{y}$ & $-p_{z}$ \\
\hline & FP & 5.0 & 0.04 & 0.04 & 0.01 & 120 & 0 & 300 \\
0 & SP & 28.0 & 0.24 & 0.24 & 0.07 & 0 & 0 & 570 \\
& RP & 10.8 & 0.40 & 0.30 & 0.08 & -100 & 0 & 270 \\
& Wh & 3.6 & 0.12 & 0.06 & 0.12 & 0 & 0 & 778 \\
\hline 1 & FP & 35.4 & 1.27 & 1.27 & 0.42 & 64 & 9 & 273 \\
2 & FP & 41.7 & 1.73 & 1.71 & 0.45 & 54 & 17 & 227 \\
3 & FP & 32.1 & 1.27 & 1.28 & 0.35 & 70 & 0 & 278 \\
4 & FP & 45.6 & 1.64 & 1.71 & 0.45 & 46 & 17 & 229 \\
5 & FP & 31.6 & 1.11 & 1.13 & 0.35 & 70 & 0 & 291 \\
6 & FP & 40.2 & 1.60 & 1.60 & 0.46 & 56 & 0 & 241 \\
\hline $1 \sim 5$ & RP & 9.5 & 0.24 & 0.19 & 0.05 & -230 & 0 & 170 \\
6 & RP & 4.2 & 0.11 & 0.09 & 0.02 & -225 & 0 & 186 \\
\hline \multirow{3}{*}{$1 \sim 6$} & IP & 4.5 & 0.04 & 0.01 & 0.03 & 218 & 0 & 150 \\
& SP & 7.2 & 0.03 & 0.04 & 0.03 & 0 & 80 & 744 \\
& Wh & 3.6 & 0.12 & 0.06 & 0.12 & 0 & 240 & 778 \\
\hline
\end{tabular}

(Parts abbreviations) FP: front part RP: rear part IP: intermediate plate SP: steering plate Wh: wheel part
(Extra internal loads $[\mathrm{kg}]$ )

Seg1: extra servo-amp (5.8)

Seg2: on-board computer (12.1)

Seg3: attitude sensor (2.5)

Seg4: battery-pack (16.0)

Seg5: DC-DC converter (2.0)

Seg6: AC-DC converter (10.6)
めた。

\section{2 簡略化のための設定条件}

\subsection{1 車輪部のモデル化}

KR-II が走行する際には夕イヤと路面が複数点で同時に接触 するが，凹凸面走行の際の接触状態は夕イヤの種類や地形に大 きく依存する。また，このような状態を正確に測定するための センサ系や, 地形データを探るような計測系を各車輪に装備し, 実時間制御に用いることは非常に困難である，そのため，本論 文ではタイヤ部に関して

(1) 厚さのない一定半径の円板とする

（2）凹凸面においても夕イヤは水平な路面と接する

という条件を設定する。ただし，上記条件は各車輪に独立で考 えるので，凹凸路面を走行する場合には各車輪が接する水平面 は同一ではないことに注意されたい。

\section{2 .2 その他の簡略化}

(1) 外部接触力：蛟龍の操舵運動では車輪横力は小さく抑えら れている. また, 推進方向の加減速も緩やかに行うことに より姿勢安定性への影響は小さい。さらに，車輪と路面間 に働くモーメントも小さいため，それらの影響は無視でき， 車輪路面間に働く垂直方向の力 $F_{z i}$ のみを外部接触力とし て考虑することは妥当だと考えられる。よって，

$$
\boldsymbol{N}=\left[\begin{array}{llll}
F_{z 0} & F_{z 1} & \cdots & F_{z 6}
\end{array}\right]^{T} \in \boldsymbol{R}^{7}
$$

のように接触力ベクトルを定義する.

(2) 関節力変数：蛟龍では $\mathrm{z}$ 軸が常時重力加速度方向に向くよ うに姿勢制御されるため, $\theta$ 軸の運動は $\mathrm{z}$ 軸の運動と分離 して独立に計画できる特徴を有する．KR-II では $\theta$ 軸は 位置制御され，その目標旋回角度指令は [3] の操舵制御法 によって求める。一方, $\mathrm{s}$ 軸のトルク制御による車輪の加 減速運動は姿勢制御に考慮できるが, 全体の推進運動に加 減速が加わるのは望ましくない，そのため，KR-II では車 輪の目標駆動トルク指令值を胴体速度制御法 [3]によって 求め, 姿勢制御とは独立に実施する。このような理由から $\mathrm{z}$ 軸関節力のみを最適化対象に設定する.

$$
\boldsymbol{\tau}=\left[\begin{array}{llll}
f_{z_{0}} & f_{z_{1}} & \cdots & f_{z_{6}}
\end{array}\right]^{T} \in \boldsymbol{R}^{7}
$$

ただし， $f_{z_{0}}$ は演算上の特異点を回避するために導入され ており，演算結果としては常に $f_{z_{0}}=0$ となる.

(3) バランス式： $\mathrm{z}$ 軸方向の力の釣合いと $\mathrm{x}$ と $\mathrm{y}$ 軸回りのモー メントの釣合い式のみを考慮する。よって，バランス式 $\boldsymbol{P} \boldsymbol{N}=\boldsymbol{Q}$ において $\boldsymbol{Q} \in \boldsymbol{R}^{3}$ ，そして $\boldsymbol{P} \in \boldsymbol{R}^{3 \times 7}$ となる。

(4) 一般化加速度: 運動方程式とバランス式を求める際, KR-II の 26 自由度の一般化座標系の一部のみ, $\boldsymbol{q}_{s}=$

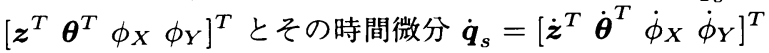
を考慮する。また，加速度は

$$
\ddot{\boldsymbol{q}}_{a}=\left[\begin{array}{lllll}
\ddot{x}_{0} & \ddot{y}_{0} & \ddot{z}_{0} & \ddot{\phi}_{X} & \ddot{\phi}_{Y}
\end{array}\right]^{T}
$$

と簡略化し， $\ddot{\boldsymbol{q}} \equiv \ddot{\boldsymbol{q}}_{a}$ としてバランス式や運動方程式に考 慮する。

（5）その他のパラメータ：導出した運動方程式の細部は紙面の 


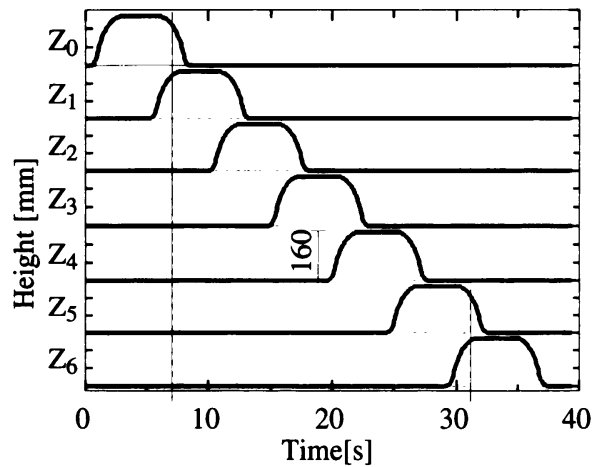

(a) Wheels vertical displacements

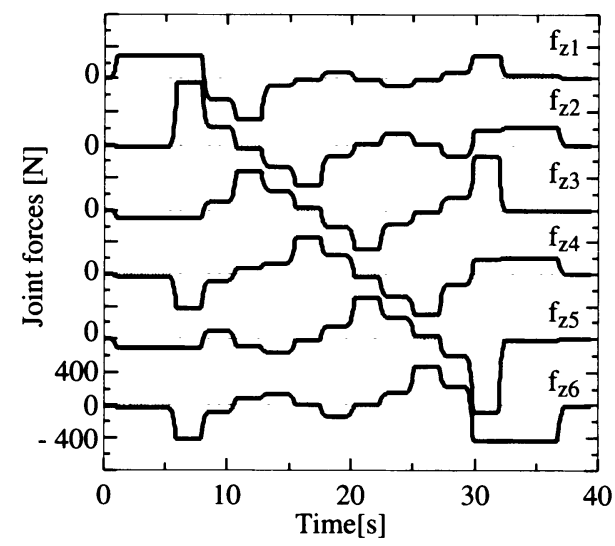

(c) z-axes joint forces

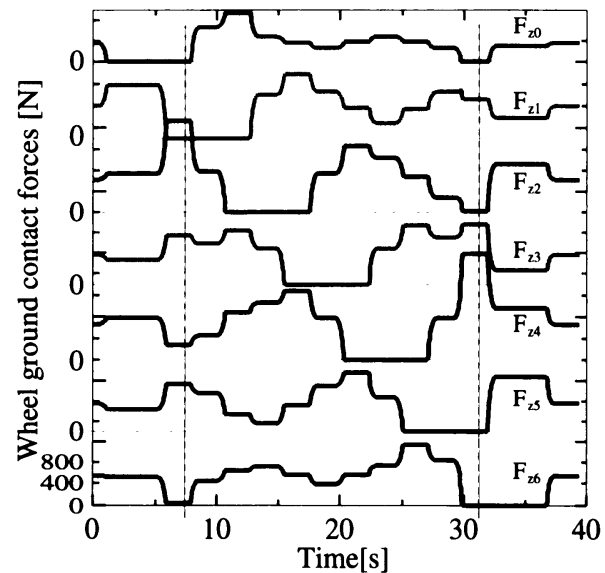

(b) Wheel-ground contact forces

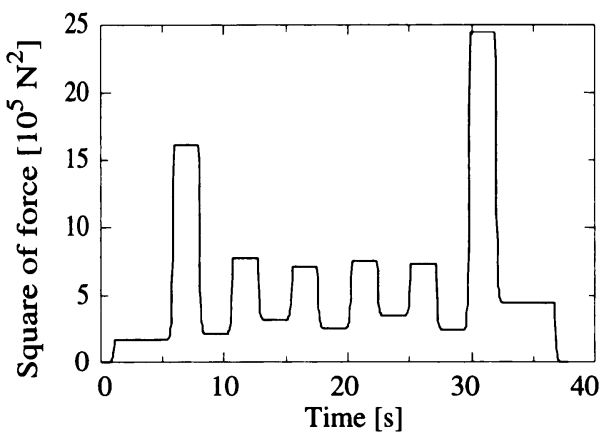

(d) Sum of squares of $z^{-}$-axes joint forces

Fig. 5 Obstacle passing over simulation

都合上本文で示すことができないが，上記の簡略化を適用 した結果，その他の諸パラメー夕の次元は， $\boldsymbol{H} \in \boldsymbol{R}^{7 \times 5}$, $\boldsymbol{C} \in \boldsymbol{R}^{7}, \boldsymbol{G}_{g} \in \boldsymbol{R}^{7}, \boldsymbol{J} \in \boldsymbol{R}^{7 \times 7}, \boldsymbol{P}_{d} \in \boldsymbol{R}^{d \times 7}, \boldsymbol{Q}_{d} \in \boldsymbol{R}^{d}$ となる.

\section{3 姿勢フィードバック項の導入}

前章の最適化問題は基本的には逆動力学演算法であり, 任意 姿勢でバランスするための各関節の目標力を算出している。 と ころが, 実際の蛟龍の制御においてはモデル化誤差や外乱など の影響によって目標姿勢に完全に追従できない，そのため，実 際の制御では胴体を目標姿勢に戻す復帰モーメントを生成させ るため, 胴体固定の基準座標系に対する姿勢角加速度フィード バック則を式（21）に導入し，以下のように与えることにする.

$$
\begin{aligned}
& \ddot{\phi}_{X}=\ddot{\phi}_{X_{d}}+K_{P_{X}}\left(\phi_{X_{d}}-\phi_{X_{m}}\right)-K_{D_{X}} \dot{\phi}_{X_{m}} \\
& \ddot{\phi}_{Y}=\ddot{\phi}_{Y_{d}}+K_{P_{Y}}\left(\phi_{Y_{d}}-\phi_{Y_{m}}\right)-K_{D_{Y}} \dot{\phi}_{Y_{m}}
\end{aligned}
$$

ただし， $K_{P}, K_{D}$ はそれぞれ比例ゲインと微分ゲイン，添え字 $d$ は目標値, 添え字 $m$ は測定值を意味する. 本手法は計算卜 ルク法 (Computed Torque Method) [30] の概念に従うもので あり, 制御安定性などに関する考察は同様に導くことが可能で ある。
5. シミュレーション

上述の定式化を用いて KR-II の障害物跨ぎ越え動作を実現 するための指令生成をシミュレーションした．障害物の形状 は幅 $300[\mathrm{~mm}]$, 高さ $150[\mathrm{~mm}]$ の箱形を想定し, 進行速度を $100[\mathrm{~mm} / \mathrm{s}]$ の一定速度として Fig 5 (a) に示す節の鉛直方向変 位の目標軌道を計画した。ただし, 変位量が $160[\mathrm{~mm}]$ となっ ているのは障害物から $10[\mathrm{~mm}]$ の余裕を持たせるためである.

\section{1 力目標値の連続性}

最適力配分問題では，車輪や脚を路面から浮かしたり着地さ せたり，または指を対象物から離したり接触させたりするトポ ロジーの変化が起きる場合に解が不連続になる。 そのため, 本 研究では跨ぎ越えを行う節の目標接地力を, 車輪が地面から離 れる際には

$$
F_{d_{n}}=F_{U p_{n}} \frac{\left(50-Z_{n}\right)}{50}
$$

とし，節が浮上状態から接地する際は

$$
F_{d_{n}}=F_{\text {Down }_{n}} \frac{\left(50-Z_{n}\right)}{50}
$$

と変化させ, 3.4 節のアルゴリズム Step 0. で $\boldsymbol{P}_{\boldsymbol{d}} \boldsymbol{N}=\boldsymbol{Q}_{\boldsymbol{d}}$ の条件式に考慮する。ここで， $F_{U p_{n}}$ は節を浮かす直前の最 適解， $F_{\text {Down n }}$ は節が地面に接地した状態を仮定した最適 
解， $Z_{n}$ は Fig 5 (a) に示す節の上下量であり,これらの式は $Z_{n}=0 \sim 50[\mathrm{~mm}]$ の区間に適用する. 定数 50 は KR-II の車 輪部のサスペンション機構のストロークを考慮して定めた值で ある. 50 以上の高さでは節支持力は零に設定した。推進速度を 等速とした場合には本手法は効果的であるが，他にも節支持力 を変化させる期間だけ推進動作を停止させる方法なども考えら れる. 本手法によって, Fig 5 (b)～(c)に示すように車輪接地力 や $\mathrm{z}$ 軸力指令值は連続的に計画できた.

\section{2 同時持ち上げ節の数と最大関節力}

Fig 5 (d) に消費パワーに相当する $\mathrm{z}$ 軸の力の 2 乗和を示す が，眓中 10 秒から 28 秒の区間内で消費パワーが上に突き出て いる部分では 2 節同時浮上，凹んだ部分は 1 節浮上状態を表し ている，KR-II では隣接した節を同時に 2 節以上持ち上げると 静的バランスを維持し難い，ところが，Fig 5 (b) で確認できる ように第 0 節と第 1 節が同時に持ち上げられる 7.5 秒付近では 第 6 節の節支持力 $F_{z 6}$ も零に計画される．また，第 5 節と第 6 節を同時に持ち上げる 32 秒付近では第 0 節と第 2 節の節支持 力 $F_{z 0}$ と $F_{z 2}$ も零に計画されている. このように, 全体のバ ランスを維持するためには最大で 4 節まで接地力零状態になる ことが 3.4 節で導入したアルゴリズムでは行われている. 端部 2 節を同時に持ち上げる運動に関しては，実際には先頭部では 3 節, 後部では 4 節が同時に接地力零になるため, それに比例 した大きな関節力とパワーが要求される。その様子が Fig 5 (c) (d) で確認できる. 本最適化問題では関節力の上限を制約条件 に考虑しなかったが，実際の KR-II では最大 $2,000 \mathrm{~N}$ 程度の出 力を許容する設計になっているため, Fig 5 (c) で計算された関 節力は実機で実現可能である.

\section{6. 実 験 結 果}

前節の障害物跨ぎ越え動作シミュレーションに対する Fig 5 (c) の力フィードフォワード指令に, 式 $(22)$ と式 (23) から計算 されるフィードバック指令を合わせて $\mathrm{z}$ 軸力サーボ系に与え た.ただし, 姿勢フィードバックゲインは $K_{P_{X}}=65, K_{D_{X}}=$ $18, K_{P_{Y}}=95, K_{D_{Y}}=16$ と設定し，すべての演算は $\mathrm{KR}-\mathrm{II}$ に搭載されている $486 \mathrm{DX} 2-50 \mathrm{MHz}$ 仕様の計算機によってサン プリング時間 $20[\mathrm{~ms}]$ で実時間に行った。

その結果, 計画された節接地力や関節力はシミュレーション された通りに再現された。例えば，接地力がゼロになった第 5 節が路面から浮上していることが Fig 6 の例から確認できる. また，Fig 7 (b) には実測した $\mathrm{z}$ 軸力の 2 乗和を示すが，力の 変化履歴はシミュレーション結果 Fig 5 (d) と傾向が一致してい ることがわかる。さらに，Fig 7 (a) で示すように複数の節支持 力が同時に零となる区間では大きな姿勢変化が起きているが, 全体としては $\pm 4^{\circ}$ 以内の偏差で安定な姿勢制御が実施されて いる.このように, 接地力 $F_{z i}$ や関節力 $f_{z_{i}}$ に関する Fig 5 の シミュレーションやFig 7 の実験結果から, 提案した動的手法 に基づく姿勢制御法の妥当性は確認できた.

ところで， $\mathrm{z}$ 軸力制御のみでは節を目的高さに自動的に調整 できず，浮上する節に対しては $z_{d i}=Z_{i}-Z_{i-1}(i=1 \sim 6)$ を目標指令とした $\mathrm{z}$ 軸位置制御系を導人する必要がある.とこ ろが、これまで KR-IIで試みた位置制御系では安定な高さ調整

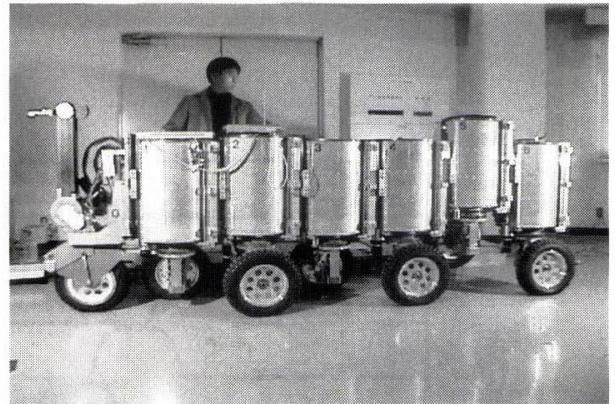

Fig. 6 Experiment overview

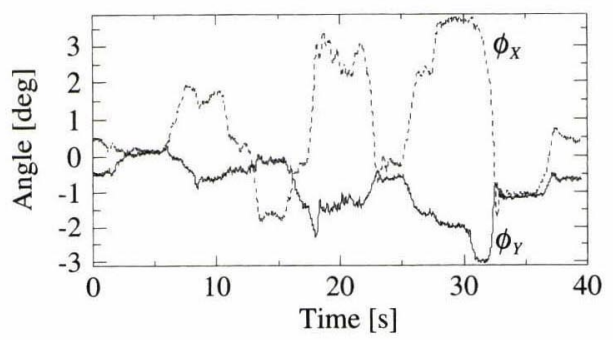

(a) Attitude displacements

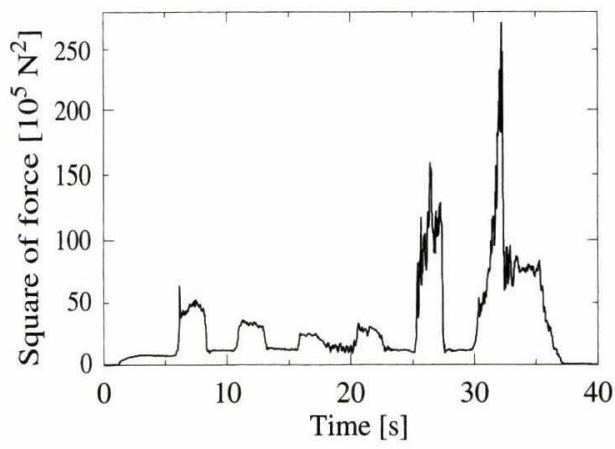

(b) Sum of squares of $\mathrm{z}$-axes joint forces

Fig. 7 Obstacle passing over experiment results

が得られず， $\mathrm{z}$ 軸位置制御の振動が全体の姿勢制御に悪影響を 及ぼした。そのため, Fig 7 の実験では位置制御を実施しなかっ た。しかし，前述の通り本論文でシミュレーションした障害物 跨ぎ越え動作では $50[\mathrm{~mm}]$ 以上の高さでは節支持力は零に設定 してあるため，Fig 5 (a) の節高さを実現できなくても Fig 5 (b) (c) に示古節支持力や関節力は変わらない. そのため, $\mathrm{z}$ 軸位置 制御なしでも本論文で議論した最適力配分を考慮した計算卜ル ク法に基づく姿勢制御の有効性は上述のシミュレーションや実 験によって検証できたと結論づけられる。ただし，今後は節が 浮上した後に $\mathrm{z}$ 軸サーボをアナログ位置制御系に切り替える方 法を導入し, 安定な節高さ制御によって完全な障害物や溝の乗 越え動作の実現を試みる。

\section{7. ま と め}

節体幹型移動ロボットは溝の乗り越えやパイプの跨ぎ越え動 作を可能にする機構構成を成しているが, 車輪を路面から浮上 させた場合でも安定した運動を実現する姿勢制御法が未だ実 
現されていなかった。そこで, 本論文ではロボット全体の力と モーメントの動的釣合式を考慮し逆動力学的手法に基づいた姿 勢制御法を新しく導入した。提案した姿勢制御法とは，胴体の 内部力 ( $\mathrm{z}$ 軸力 ) の能動的な制御によって複数の車輪一路面間 の節支持力を変化させて胴体を任意姿勢にあやつる制御法であ ると解釈できる，具体的には関節力のノルム最小化問題を節支 持力配分 (内力) を変数とした一般的な 2 次計画問題に帰着さ せ，不等式制約条件も含めた効率的な解法を提案した。本手法 の妥当性はシミュレーションと実機実験によって検証した.

今後の課題としては慣性パラメータなどをより正確に求める ための同定法の導入, そして同定後にも存在するであろうモデ ルの不確かさに対応するためのロバスト制御手法の適用, そし て実験を用いた総合的な対地適応走行実験の実施などであり, それらの点は今後引き続き検討していく予定である.

\section{参 考 文 献}

[1] 広瀬茂男, 森島昭男：“節体幹型移動ロボット「蛟龍」の基本的運 動調整”, 計測自動制御学会論文集, vol.25, no.12, pp.1331-1338, 1989.

[2] 広瀬茂男, 森島昭男, 塚越真一, 妻木俊道, 物部宏之: “節体幹 型移動ロボットKRIIの開発”, 日本ロボット学会誌, vol.9, no.5, pp.551-559, 1991.

[3] 福島 E. 文彦, 広瀬茂男: “節体幹型移動ロボットの絶対座標型操舵 制御”, 日本ロボット学会誌, vol.14, no.4, pp.523-531, 1996.

[4] K.J. Waldron, V. Kumar and A. Burkat: "An actively coordinated mobility system for a planetary rover," Proc. 1987 ICAR, pp. $77-86,1987$.

[5] Commissariat A I'Energie Atomique: "Rapport d'activite 1987," Unité de Génie Robotique Avancé, France, 1987.

[6] J.W. Burdick, J. Radford and G.S. Chirikjian: "Hyperredundant robots: kinematics and experiments," International Symposium on Robotics Research, pp.1-16, 1993.

[7] D. Tilbury, O.J. Sordalen and L. Bushnell: "A Multisteering Trailer System: Conversion into Chained Form Using Dynamic Feedback," IEEE Transactions on Robotics and Automation, vol.11, no.6, pp.807-818, 1995.

[8] 築島隆尋, 高野政晴, 佐々木健, 井上健司：“車輪式移動ロボットの 運動学および動力学の一般理論に関する研究”, 日本ロボット学会誌, vol.8, no.6, pp.699-711, 1990.

[9] 酒井秀男: “車輪移動機構の $\mathrm{ABC}$ 一タイヤの力学”, 日本ロボット学 会誌, vol.13, no.1, pp.113-118, 1995.

[10] K. Thanjavur and R. Rajagopalan: "Ease of Dynamic Modelling of Wheeled Mobile Robots (WMRS) using Kane's Approach," Proc. of IEEE Intl. Conference on Robotics and Automation, pp.2926-2931, 1997

[11] Y. Shan and Y. Koren: "Design and Motion Planning of a Mechanical Snake," IEEE Transactions on System, Man and Cybernetics, vol.23, no.4, pp.1091-1100, 1993.

[12] M. Nilsson: "Snake Robot Free Climbing," Proc. IEEE Intl.
Conference on Robotics and Automation, pp.3415-3420, 1997.

[13] G. Migads and J. Kyriakopoulos: "Design and Forward Kinematic Analysis of a Robotic Snake," Proc. IEEE Intl. Conference on Robotics and Automation, pp.3493-3497, 1997.

[14] 広瀬茂男：ロボット工学—機械システムのベクトル解析一.pp.22-26, 裳華房, 1987.

[15] J. Kerr and B. Roth: "Analysis of Multifingered Hands," The Intl. Journal of Robotics Research, vol.4, no.4, pp.3-17, 1986.

[16] 中村仁彦, 永井清, 吉川恒夫 : “複数のロボット機構による協調あや つりの力学”, 日本ロボット学会誌, vol.4, no.5, pp.489-498, 1986.

[17] I.D. Walker, R.A. Freeman and S.I. Marcus: "Dynamic Task Distribution for Multiple Cooperating Robot Manipulators," Proc. IEEE Intl. Conf. on Robotics and Automation, pp.1288$1290,1988$.

[18] Y. Nakamura, K. Nagai, T. Yoshikawa: "Dynamics and Stability in Coordination of Multiple Robotic Mechanisms," The Intl. Journal of Robotics Research, vol.8, no.2, pp.44-61, 1989.

[19] 広瀬茂男, 福島 E. 文彦, 森島昭男: “節体幹型移動ロボット「蛟龍」 の研究, 第 11 報基本的運動調整系の実現”, 第 9 回ロボット学会学 術講演会予稿集, pp.311-314, 1991.

[20] 福島 E. 文彦, 広瀬茂男, 林丈雄：“節体幹型移動ロボット「蛟龍」の 研究, 第 15 報バランス式に基づく姿勢制御の提案”，第 14 回ロボッ 卜学会学術講演会子稿集, pp.609-610, 1996.

[21] F.T. Cheng and D.E. Orin: "Optimal Force Distribution in Multiple-Chain Robotic Systems," IEEE Transactions on Systems, Man, and Cybernetics, vol.21, no.1, pp.13-24, 1991.

[22] M.A. Nahon and J. Angeles: "Real-Time Force Optimization in Parallel Kinematic Chains under Inequality Constraints," IEEE Trans. on Robotics and Automation, vol.8, no.4, pp.439450, Aug. 1992 ,

[23] 古川恒夫：“把持と操りの基礎理論”, 日本ロボット学会誌, vol.14, no. 1, pp. $48-54,1996$.

[24] M. Buss, H. Hashimoto and J. Moore: "Dextrous Hand Grasping Force Distribution," IEEE Transactions on Robotics and Automation, vol.12, no.3, pp.406-418, 1996.

[25] J.-S. Chen, F.-T. Cheng, K.-T. Yang, F.-C. Kung and Y.-Y. Sun: "Solving the Optimal Force Distribution Problem in Multilegged Vehicles," Proc. of the 1998 IEEE Intl. Conf. on Robotics and Automation, pp.471-476, Belgium, May 1998.

[26] D.W. Markefka and D.E. Orin: "Quadratic Optimization of Force Distribution in Walking Machines," Proc. of the 1998 IEEE Intl. Conf. on Robotics and Automation, pp.477-483, Belgium, May 1998

[27] D. Goldfarb, A. Idnami: "A numerically stable dual method for solving strictly convex quadratic programs," Math. Programming, vol.27, pp.1-33, 1983.

[28] 茨木俊秀, 福島雅夫：FORTRAN77 最適化プログラミング. 岩波書 店, pp.87-132, 1991.

[29] ASNOP 研究会編：パソコン FORTRAN 版非線形最適化プログラ ミング. 日刊工業新聞社, pp.41-56, 1991.

[30] B.R. Markiewics: "Analysis of the Computer Torque Drive Method and Comparison with Conventional Position Servo for a Computer-Controlled Manipulator," Jet Propulsion Laboratory, California Institute of Technology, TM 33-601, Mar. 1973.

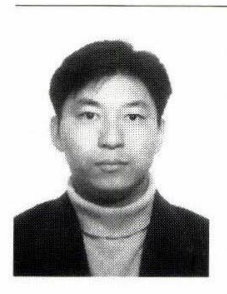

福島 E. 文彦 (Edwardo F. Fukushima) 1967 年 4 月 14 日生. 1993 年東京工業大学機械物 理工学専攻修士課程卒業. 同年同大学博士課程入 学, 1994 年 8 月から東京工業大学工学部機械宇宙 学科助手, 現在に至る. 移動ロボットの制御, DC モータ駆動装置, テザーを用いた連結機構の研究 に従事.

(日本ロボット学会正会員)

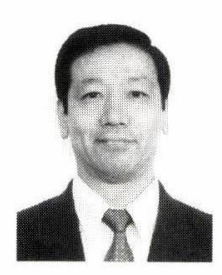

広瀬茂男（Shigeo Hirose）

1947 年 12 月 6 日生. 1976 年東京工業大学制御工 学専攻博士課程修了. 工学博士. 同年同大学機械 物理工学科助手, 1979 年同大学助教授, 1992 年同 大学教授, 現在に至る。ロボットの機構, センサ, 制御の研究に従事.
(日本ロボット学会正会員) 